\title{
The Improvement of Employee Performance Through Islamic Leadership, Emotional Quotient, and Intrinsic Motivation
}

\author{
Wuryanti Kuncoro ${ }^{1}$, Alfazar Edi Putra ${ }^{1}$ \\ ${ }^{1}$ Faculty of Economics, Universitas Islam Sultan Agung, Semarang, Indonesia \\ Correspondence: Wuryanti Kuncoro, Faculty of Economics, Universitas Islam Sultan Agung, Semarang, \\ Indonesia.
}

Received: December 20, 2019

Accepted: January 20, 2020

Online Published: January 20, 2020

doi:10.5539/ibr.v13n2p90

URL: https://doi.org/10.5539/ibr.v13n2p90

\begin{abstract}
Improving good employee performance can have an impact on company success, employees are always required to work optimally where good or poor employee performance can affect overall company income. One of the most important in improving employee performance is Intrinsic Motivation. This study aims to determine and analyze the influence of Islamic leadership, emotional quotient, intrinsic motivation on employee performance. The population of this research is all employees at Sultan Agung Islamic Hospital Semarang, Indonesia. The number of samples studied in this study was 100 respondents with a purposive sampling technique, that is by determining specific characteristics in accordance with the research objectives. Data analysis in this study used multiple regression analysis. The results of this study indicate that there is an influence between Islamic leadership on employee performance, emotional quotient on employee performance, intrinsic motivation on employee performance, Islamic leadership on intrinsic motivation, and emotional quotient on intrinsic motivation.
\end{abstract}

Keywords: Islamic leadership, emotional quotient, intrinsic motivation, employee performance

\section{Introduction}

In the era of globalization, technology and information are inseparable in all aspects of human life, as like company, it wants to continue to thrive and grow. Furthermore, the rapid growth of technology and information that is increasingly sophisticated, detailed, and also followed by competitive competition.

Demands given to employees will certainly cause burnout or high-stress levels. This requires internal encouragement so that employees remain optimal at work. Related to the problems that exist in the performance of discipline, motivation, and job satisfaction, one of the most important things in improving employee performance is the existence of motivation in an employee, or can be called as "Intrinsic Motivation".

Intrinsic motivation is a motivation that encourages a person to excel from an individual. Good and Brophy (1990: 367) state that intrinsic motivation depends on the perception that a person's behavior arises more from internal causes than external pressure. Intrinsic motivation will decrease if one's feelings of competence and self-determination decrease. Furthermore, the effects of an action include feedback and rewards that consist of controlling elements and informational elements.

Leadership has a character that is synonymous with strength because that strength can later lead an employee to achieve the company's vision and mission. In the era of globalization, behavior does not further deviate from what must be done actually, companies need leaders who have a strong religious foundation to guide and direct their employees.

In terms of work, emotional factors also affect organizational success. Not optimal someone in managing emotions can also cause performance to be hampered. Goelman (2000) stated that the higher the level of work, the more important emotional quotient. Emotional Quotient (EQ) becomes an influence in a person. Similarly, employees who have high emotional quotient will also have a high commitment to a company or organization.

Some research results show employees who have emotional quotient, the level of obedience and responsibility for their work will be attached to their character. Also, employees can control and manage their emotions and also establish harmonious relationships with colleagues, the environment in which they live, can manage themselves, have initiative, a sense of optimism, able to do and complete all their work calmly without having emotions (Boyatzis, 2001). 
Sultan Agung Hospital in Semarang is one of the Hospitals owned by the Islamic organization of the City of Semarang which is modeled as General Hospital, under the auspices of Sultan Agung Islamic Hospital and listed in Type B Hospital. Based on these data, it can be seen that the number of employees who are not disciplined in working reaches an average per year as many as $4.04 \%$ ( 831 people). This resulted in an indication of problems with performance degradation in the company. Therefore, it is necessary to study on the previous studies and combines them to obtain a complete framework that will explain how a company improves the performance of existing employees.

Based on the description above, researchers are interested in examining the influence of Islamic leadership and emotional quotient on intrinsic motivation, and the influence of Islamic leadership and emotional quotient on employee performance. Therefore, this study is entitled "the Improvement of Employee Performance through Islamic leadership, emotional quotient, and intrinsic motivation". The purpose of this study was to determine the effect of Islamic leadership and emotional quotient on intrinsic motivation, Islamic leadership, emotional quotient, and intrinsic motivation on employee performance.

\section{Literature Review}

\subsection{Theoretical Background}

Technology and information are inseparable in all aspects of human life, as like company, it wants to survive and develop. The company will get a positive impact because it will further support the effectiveness and efficiency of work. The size of an employee's performance can be measured by considering the quantity (the amount that must be completed and achieved), Quality (the quality produced is good or not), Timing (specified time).

According to (Winardi, 1996), performance comes from the word 'job performance' or 'actual performance' (work performance or actual achievement by someone).

Islam is a religion that rewards the hard work of its people. Islam gives teachings to its people to always carry out hard work in terms of worship or pious deeds. Hard work behavior has been exemplified by the Prophet Muhammad. He taught his people that we as people in life should not only spend time remembering Allah. That is why Allah and His Messenger commanded us to get accustomed to hardworking behavior that is not dependent on others. In the Holy Qur'an, Taubah (9): 105 which means:

\section{And say, "Do [as you will], for Allah will see your deeds, and [so, will] His Messenger and the believers. And you will be returned to the Knower of the unseen and the witnessed, and He will inform you of what you used to do."}

Based on the word of God above, it is concluded that the performance of every Muslim is done earnestly not only to benefit himself but also to others by hoping for the pleasure of Allah SWT. Tjahjono (2003) explains that there are two types of factors that encourage a person to try to achieve satisfaction and distance themselves from dissatisfaction. The two factors are the Hygiene Factor (extrinsic factor) and the Motivator Factor (intrinsic factor). Intrinsic motivation is the motivation that encourages a person to excel that comes from the individual.

Leadership is an act of influencing others to put more effort into directing energy, in their work or changing their behavior (Amaliya, 2016). Thus, it can be concluded that the problem of leadership is a social problem in which there is an interaction between leaders and subordinates for common goals, both by influencing, persuading, motivating, and coordinating. Islamic leadership is a nature for every human being who at the same time motivates Islamic leadership. Humans are mandated by Allah to be the caliph of Allah (Allah's representative) on earth (Holy Qur'an, Al-Baqarah: 30). The caliph was in charge of realizing his sacred mission as a bearer of mercy to the universe and at the same time, they become an 'abdullah' (servant of God) who is always obedient and called to devote all his dedication in the way of Allah.

Based on the description above, it can be stressed that Islamic leadership is a process or ability of people to direct and motivate the behavior of others, and the existence of cooperative efforts in accordance with the contents of the Al-Quran and Hadith to achieve the desired goals together.

Goleman (2000: 45) explains that emotional quotient is an ability such as to motivate oneself, defense against frustration, control impulses and not exaggerate pleasure, regulate moods and keep stress away from crippling the ability to think, empathize and pray.

\subsection{Hypothesis Development}

\subsubsection{Relationship Between Islamic leadership and Intrinsic Motivation}

Khasanah (2016) states that leadership influences motivation. In the Islamic teachings, every human being is a leader and will certainly be held accountable by the Giver of Trust (Allah). The difference only lies in the 
community, quantity, scope, and the symbols of leadership. In Islam, it also has been explained clearly about the role of a good leader in motivating his subordinates, as stated in Surah Al-Anbiya verse 73: "And we have made them as leaders who give instructions with our orders and We have revealed to them that they do good, establish prayers, pay zakat, and we only worship them".

Based on the verse above, it can be drawn that a wise leader is a leader who can provide instructions in the form of motivation and good direction to his subordinates. Motivation and direction given is good motivation (Sandi, 2014). Thus, hypothesis is proposed as:

H1: Islamic leadership has a positive effect on intrinsic motivation

\subsubsection{Relationship Between Emotional Quotient and Intrinsic Motivation}

Dewi (2014) shows that there is a relationship between emotional quotient and learning motivation with student learning independence. From the description, it is explained that emotional quotient and learning motivation have contributions in optimizing the realization of learning independence. Therefore, students who have good emotional quotient and high learning motivation will have good learning independence and vice versa. In this case, emotional quotient strongly underlies the emergence of a person's intrinsic motivation to carry out activities. Based on the results of previous studies, hypothesis is proposed as:

$\mathrm{H} 2$ : Emotional quotient has a positive effect on intrinsic motivation

\subsubsection{Relationship Between Islamic Leadership and Employee Performance}

Harahap (2016) shows that the Islamic leadership variable has a positive effect on employee performance. In previous studies, Wajdi (2012) showed that Islamic leadership had a significant positive effect on employee performance. Based on the results of previous studies, hypothesis is proposed as:

H3: Islamic leadership has a significant effect on employee performance

\subsubsection{Relationship Between Emotional Quotient on Employee Performance}

Nasution (2009) states that emotional quotient is the ability to use emotions effectively in achieving goals, building relationship productivity and achieving success. This ability is one of the factors of the quality of employee performance which is one of the factors that drives the success of company performance.

Dewi (2016) states that emotional quotient has a significant effect on employee performance. Based on the results of previous studies, hypothesis is proposed as:

H4: Emotional quotient has a significant effect on employee performance.

\subsubsection{Relationship Between Intrinsic Motivation on Employee Performance}

Taufiq (2016: 173) stated that intrinsic motivation has a significant effect on employee performance. Maulana (2015) confirm that there was a positive and significant influence between intrinsic motivation on employee performance. Based on the results of previous studies, hypothesis is proposed as:

H5: Intrinsic motivation has a significant effect on employee performance.

\subsection{Empirical Research Model}

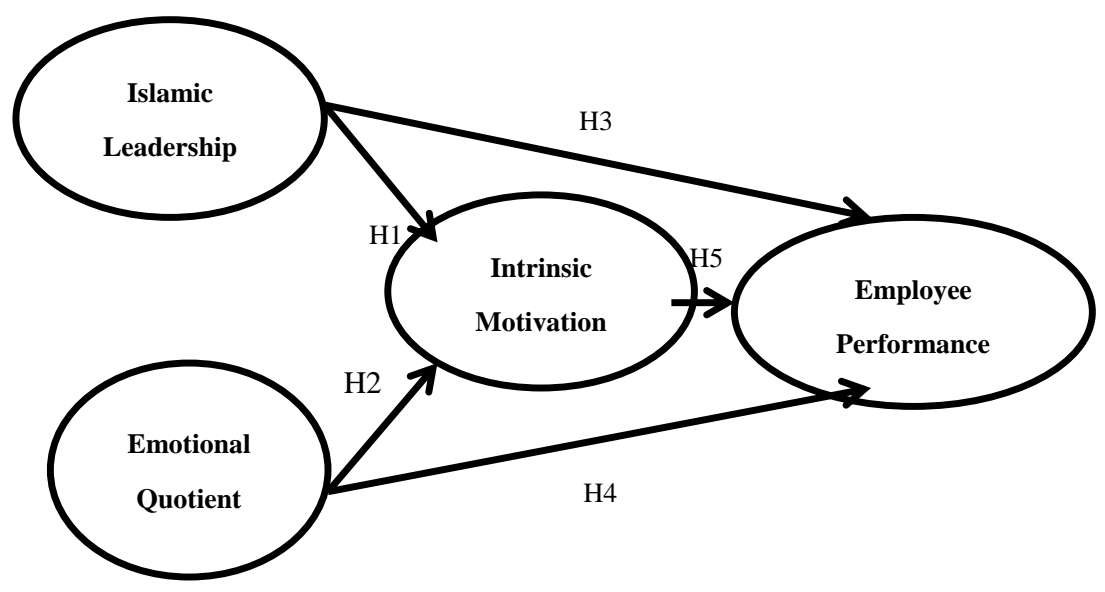

Figure 1. Empirical Research Model 
The empirical model illustrates the relationship between the following variables: (a) Relationship between Islamic leadership and Intrinsic Motivation as the first hypothesis (H1), (b) Relationship between Emotional Quotient and Intrinsic Motivation as the second hypothesis (H2), Relationship between Islamic Leadership and Employee Performance as Employee Performance as the third hypothesis (H3), Relationship between Emotional Quotient and Employee Performance as the fourth hypothesis (H4), Relationship between Intrinsic Motivation and Employee Performance as the fifth hypothesis (H5).

\section{Research Methodology}

\subsection{Type of Research}

This type of research is a qualitative research method. (Sugiyono, 2010) stated that qualitative research is a method based on the philosophy of post-positivism, used to examine natural conditions of objects where researchers are as a key instrument, data source sampling is done purposively, data collection techniques used triangulation, data analysis are inductive or qualitative, and qualitative research results emphasize more meaning than generalization.

\subsection{Population and Sample}

The subject of this research is the Employees at Sultan Agung Islamic Hospital Semarang.

The population is a generalization area that consists of objects or subjects that make certain quantities and characteristics determined by researchers and then drawn conclusions (Sugiyono, 2007: 90). The population in this study were employees of Islamic Sultan Agung Hospital Semarang with a total of 831 people, consisting of non-medical and medical employees who were divided into permanent employees, temporary employees, prospective employees, and contract employees.

Sample is part of the number and characteristics possessed by the population (Sugiyono, 2007: 57). Sample must be as large as possible. The more samples were taken the more representative and the results can be adjusted. Meanwhile, according to Yusuf (2014: 150), the sample is a portion of the population chosen and represents that refers to the characteristics of the population in a certain amount on each characteristic. So, the sample is a portion of the population that represents in accordance with the characteristics.

The sampling method used was Purposive Sampling. The method is a technique for determining the sample with certain considerations.

Table 1. Population and Sample

\begin{tabular}{cccc}
\hline Department & Total Members & Formula & Sample \\
\hline Personnel & 115 & $\frac{115}{831} \times 100$ & 13,8 or 14 \\
Staff & 28 & $\frac{28}{831} \times 100$ & 3,36 or 3 \\
Nurse & 688 & $\frac{688}{831} \times 100$ & 82,7 or 83 \\
\hline Total & 831 & & 100 \\
\hline
\end{tabular}

Source: Islamic Sultan Agung Hospital Semarang, 2016

\subsection{Data Collection Techniques}

In this study, the data source used is primary data. Primary data is a data source that directly provides data to data collectors (Sugiyono, 2012: 30). The primary data in the researcher is from the questionnaire filled by the employees of Islamic Sultan Agung Hospital Semarang.

To collect the data needed in this study, several methods are used as follows:

1. Questionnaire is a data collection technique that is done by giving a set of written questions to respondents to answer (Sugiyono, 2010: 199)

2. Observation refers to a data collection technique that has specific characteristics when compared with other data collection techniques, namely interviews or questionnaires (Sugiyono, 2010: 203). 
Measurement data in this study using open and closed questions. Determination of the scoring of the answers to each question from each respondent can be seen in table 2 .

Table 2. Respondents' Answer Score

\begin{tabular}{cccccc}
\hline Question & Strongly Disagree & Disagree & Neutral & Agree & Strongly Agree \\
\hline Score & 1 & 2 & 3 & 4 & 5 \\
\hline
\end{tabular}

\subsection{Sample Description}

The population in this study were all employees of Islamic Sultan Agung Hospital Semarang. The data of this study were collected by distributing questionnaires to all employees of the Sultan Agung Islamic Hospital Semarang.

\subsection{Descriptive Statistics of Respondents}

This analysis aims to review the answers of respondents to each question that became the instrument of this study. To get a picture of the level of respondents' perceptions of the variables studied, an index number can be developed. This is done to get a descriptive picture of the respondents of this study, especially regarding the research variables used.

To illustrate the respondents' perceptions of the questions raised, this Likert scale is used. Then, the response index calculation is done with the following formula:

Index value $=((\mathrm{F} 1 \mathrm{x} 1)+(\mathrm{F} 2 \mathrm{x} 2)+(\mathrm{F} 3 \mathrm{x} 3)+(\mathrm{F} 4 \mathrm{x} 4)+(\mathrm{F} 5 \mathrm{x} 5) / 5)$

Where:

F1 is the frequency of the answers of respondents who answered 1.

F2 is the frequency of the answers of respondents who answered 2.

F3 is the frequency of the answers of respondents who answered 3.

F4 is the frequency of the answers of respondents who answered 4.

F5 is the frequency of the answers of respondents who answered 5.

From this research questionnaire, the number of respondents' answers did not start from 0 , but from 1 to 5 . Therefore, the resulting index numbers will start from 20 to 100 with a range of 80 . In this study, criteria used 3 boxes divided by 3 and resulting in a range of 26.66. The range will be used as a basis for determining the index of consumer perception of the variables used in this study, as follows:

$$
\begin{aligned}
& 73,34-100,00=\text { large } \\
& 46,67-793,33=\text { medium } \\
& 20,00-46,66=\text { small }
\end{aligned}
$$

Based on descriptive answers of respondents to the Islamic leadership variable, it shows that the indicator of managerial ability has an average of 89.6 , the work ethic has an average of 88.8 , the religious knowledge has an average of 80.8 , the intellectual ability has an average of 84.4 , and on emotional control has an average of 80.8 . This shows that respondents responded well about Islamic leadership.

Based on descriptive answers of respondents to the emotional quotient variable, it shows that the self-awareness indicator has an average of 89.4, the motivation indicator has an average of 91 , the empathy indicator has an average of 90.9 , and the social skills have an average of 89.6. This shows that the response of emotional quotient responded well by the respondents.

Based on descriptive answers of respondents to the intrinsic motivation variable, it shows that the achievement indicator has an average of 88.6, the responsibility indicator has an average of 88.6, the self-improvement indicator has an average of 88 , and the positive attitude indicator has an average of 87 . This shows that intrinsic motivation is needed by the respondents.

Based on descriptive answers of respondents to employee performance variable, it shows that the quality indicator has an average of 85.6, the quantity indicator has an average of 88.4, the effectiveness indicator has an average of 86.2, the independence indicator has an average of 86.4, and the commitment indicator has an average of 89.4. This shows that the performance of employees must be improved in order to be better at work. 


\subsection{Data Analysis Technique}

Data analysis in this research used multiple regression. Regression analysis was used to determine whether the independent variables and influence the dependent variable and to measure the strength of the relationship between two or more variables and show the direction of the relationship between the independent and the dependent variable.

\subsection{Validity Test}

A validity test is used to measure the validity of a questionnaire (Ghozali, 2014). A questionnaire is said to be valid if the questions are able to express variables that will be measured by the questionnaire. So, validity refers to determining whether the questions in the questionnaire that have been made really can measure or not. Validity test can be known by looking at $\mathrm{r}$-count and $\mathrm{r}$-table $(\mathrm{N}-2)$, then the question is said to be valid.

\subsection{Reliability Test}

The reliability test is a test tool to measure the questionnaire which is an indicator of the variable. A variable is said to be reliable if the alpha value> 0.7 (Ghozali, 2014).

\subsection{Normality Test}

The normality test aims to test whether in the data, the dependent and the independent variables have a normal distribution relationship or not. Good data has a normal or almost normal data distribution (Ghozali, 2014: 28).

\subsection{Multicollinearity Test}

Multicollinearity test aims to test whether the regression model found a correlation between independent variables. One way to detect the existing of multicollinearity is by looking at the value of the Variance Inflation Factor (VIF).

\subsection{Heteroscedasticity Test}

Heteroscedasticity test aims to test whether in the regression model, there is an inequality of variance from residuals of one observation to another. If the variance from one observation residual to another observation is fixed, then it is called homoscedasticity and if it is different is called heteroscedasticity. A good regression model is a homoscedasticity or not heteroscedasticity. Most cross-section data contain heteroscedasticity because these data collect data representing various sizes (small, medium and large) (Ghozali, 2014).

\section{Results and Discussion}

\subsection{Multiple Linier Regression Results}

The results of multiple linier regression analysis are as follows.

Table 3. Multiple Linear Regression Analysis (model 1)

\begin{tabular}{cccc}
\hline & Coefficients $^{\text {a }}$ & & \\
\hline & Standardized Coefficients & T & Sig. \\
Model & Beta & & 0 \\
(Constant) & & 3,75 & 0,000 \\
Islamic Leadership (IL) & 0,33 & 4,031 & 0,000 \\
Emotional Quotient (EQ) & 0,507 & 6,199 & \\
\hline a. Dependent Variable: Intrinsic Motivation (IM) & & & \\
\hline
\end{tabular}

Source: primary data processed 2019

The multiple linear regression equation used to analyze these variables is as follows:

$$
\mathrm{Y} 1=09.330 \mathrm{IL}+0,507 \mathrm{EQ}+\varepsilon
$$

1. Islamic leadership variable obtains a beta value of 0.330 . This means that if Islamic leadership increases by $1 \%$, then intellectual motivation will also increase by 0.330 or $33 \%$.

2. The emotional quotient variable obtained a beta value of 0.507 . This means that if emotional quotient increases by $1 \%$ then 9 intellectual motivation will also increase by 0.507 or $50.7 \%$. 
Table 4. Multiple Linear Regression Analysis (model 2)

\begin{tabular}{ccccc}
\hline \multicolumn{5}{c}{ Coefficients $^{\text {a }}$} \\
\hline & Standardized Coefficients & & T & Sig. \\
\hline 1 & Model & Beta & $-1,073$ & 0,286 \\
& (Constant) & & 5,069 & 0 \\
& Islamic Leadership (IL) & 0,356 & 5,231 & 0 \\
& Emotional Quotient (EQ) & 0,402 & 2,789 & 0,006 \\
\hline
\end{tabular}

a. Dependent Variable: Employee Performance (EP)

Source: primary data processed 2019

The multiple linear regression equation used to analyze these variables is as follows:

$$
\mathrm{Y} 2=0.356 \mathrm{IL}+0,402 \mathrm{EQ}+0,225 \mathrm{IM}+\varepsilon
$$

1. Islamic leadership variable obtains a beta value of 0.356 , this means that if the Islamic leadership increases by $1 \%$ then the employee's performance will also increase by 0.356 or $35.6 \%$.

2. Emotional Quotient variable obtains a beta value of 0.402 , this means that if emotional quotient increases by $1 \%$ then employee performance will also increase by 0.402 or $40.2 \%$.

3. Intrinsic motivation variable obtains a beta value of 0.225 , this means that if intrinsic motivation increases by $1 \%$ then employee performance will also increase by 0.225 or $22.5 \%$.

\subsection{Hypothesis Testing}

Significant Test of Individual Parameters (Statistical Test t).

Table 5. Significant Test of Individual Parameters (model 1)

\begin{tabular}{|c|c|c|c|c|}
\hline \multicolumn{5}{|c|}{ Coefficients $^{\mathrm{a}}$} \\
\hline & \multicolumn{4}{|c|}{$\begin{array}{l}\text { Standardized } \\
\text { Coefficients }\end{array}$} \\
\hline & Model & Beta & $\mathrm{T}$ & Sig. \\
\hline 1 & (Constant) & & 3,75 & 0 \\
\hline & Islamic Leadership (IL) & 0,33 & 4,031 & 0 \\
\hline & Emotional Quotient (EQ) & 0,507 & 6,199 & 0 \\
\hline
\end{tabular}

a. Dependent Variable: Intrinsic Motivation (IM)

Source: primary data processed 2019

Degrees of freedom df = n-k-1 = 100-2-1 = 97, and two-sided testing obtained a value of 1,653

1. In the Islamic leadership variable, the value of $t$-count $=4.031$ is greater than the table of 1.653 and the significance value of $0.000<0.05$, thus $\mathrm{H} 1$ is accepted. This means that the Islamic leadership statistically influences intrinsic motivation.

2. In the emotional quotient variable, the value of $\mathrm{t}$ count $=6.199$ is greater than the table of 1.653 and a significance value of $0.000<0.05$, thus $\mathrm{H} 1$ is accepted. This means that the emotional quotient variable statistically influences intrinsic motivation.

Table 6. Significant Test of Individual Parameters (model 2)

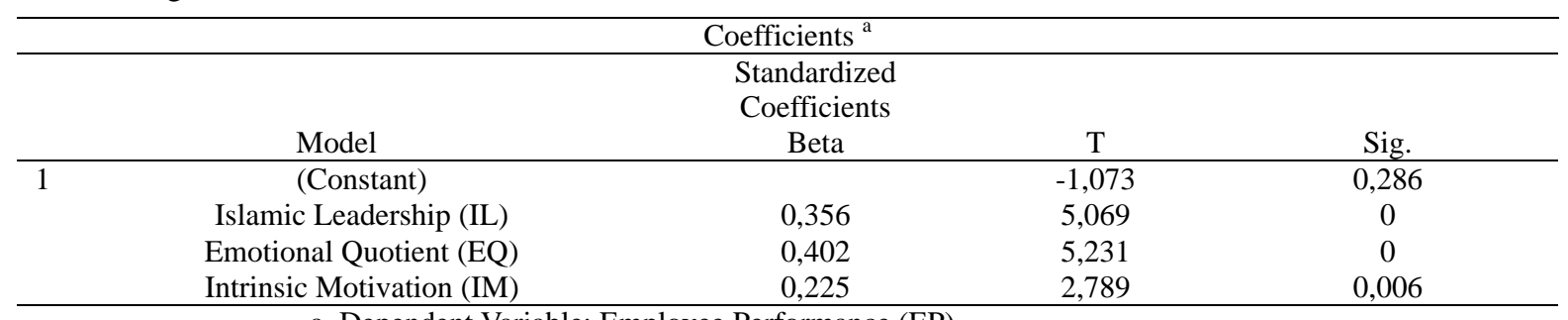

Source: primary data processed 2019 
Degrees of freedom df $=\mathrm{n}-\mathrm{k}-1=100-3-1=96$, and two-sided testing obtained a value of 1,653.

1. In the Islamic leadership variable, the calculated value of $t=5.069$ is greater than the table of 1,653 and the significance value of $0,000<0.05$, thus $\mathrm{H} 1$ is accepted. This means that the Islamic leadership statistically influences employee performance.

2. In the emotional quotient variable, the calculated value of $t=5.231$ is greater than the table of 1,653 and a significance value of $0,000<0.05$, thus $\mathrm{H} 1$ is accepted. This means that the emotional quotient statistically influences employee performance.

3. In the intrinsic motivation variable, the calculated value of $t=2.789$ is greater than the table of 1,653 and the significance value of $0.006<0.05$, thus $\mathrm{H} 1$ is accepted. This means that the emotional quotient statistically influences employee performance.

\subsection{Path Analysis}

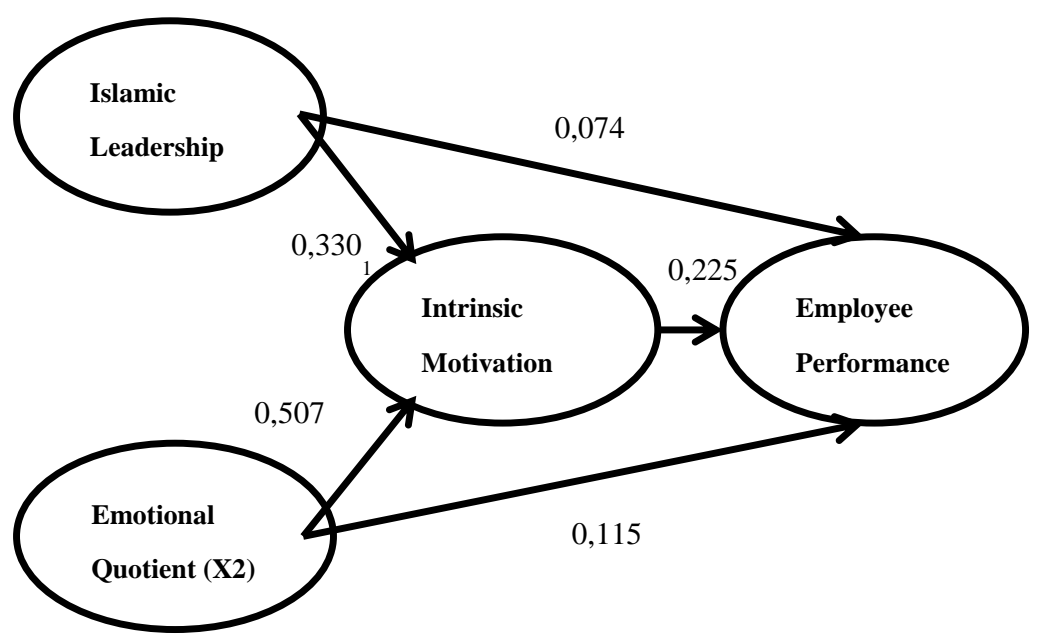

Figure 2. Total Effect

Islamic Leadership : 0,330 x 0,225=0,074

Emotional Quotient : 0,507 x 0,0255=0,115

In the total test, Islamic leadership on intrinsic motivation gained 0.330 or $33 \%$, emotional quotient on intrinsic motivation gained 0.507 or $50.7 \%$, while Islamic leadership on performance gained 0.074 or $7.4 \%$ and emotional quotient on performance gained 0.115 or $11.5 \%$.

\subsection{Discussion}

\section{Effect of Islamic Leadership on Intrinsic Motivation}

Based on the hypothesis test, it shows that Islamic leadership has a significant positive effect on intrinsic motivation, meaning that the better the Islamic leadership is implemented in the company, the better the intrinsic motivation of HR within the company. Thus, if the application of managerial skills is improved within the company, it will increase the achievement of HR in working. Meanwhile, if the Islamic work ethic given by the leader towards HR is increased, it will increase the sense of responsibility of HR towards the company. If the intellectual ability is increased, it will enhance the development of HR in the company, and if religious knowledge and emotional control are improved in the company, it will increase the positive attitude of employees on work. Therefore, it supports research conducted by Harahap (2016) which states that Islamic leadership influences intrinsic motivation.

\section{Effects of Emotional Quotient on Intrinsic Motivation}

From the hypothesis test, it shows that emotional quotient has a significant positive effect on intrinsic motivation, meaning that the higher the emotional quotient in employees, the higher the intrinsic motivation felt by employees. Thus, if the motivation of employees is increased, it will improve employee performance in the company. Meanwhile, if the empathy owned by employees is increased, it will increase employee responsibilities to the company. If employees improve social skills, it will improve employee self-development at the company, and if the self-awareness of employees is increased, it will also increase a positive attitude in the company. 
Therefore, it supports research conducted by Juliana and Rozali (2017) which states that emotional quotient influences intrinsic motivation.

\section{Effect of Islamic Leadership on Employee Performance}

From the hypothesis test, it shows that Islamic leadership has a significant positive effect on employee performance, meaning that the better the Islamic leadership is applied in the company, the better the performance of employees in the company. Thus, if managerial skills are improved, it will increase the organizational commitment of employees in the company. Meanwhile, if the Islamic work ethic is improved, it will improve the quality of employees in the company. If the intellectual abilities of employees are increased, it will increase the independence and quantity of employees in the company. If religious knowledge and emotional control are improved in employees, it will increase work effectiveness in the company. Therefore, it supports research conducted by Muizu (2014) which states that Islamic leadership influences employee performance.

\section{Effect of Emotional Quotient on Employee Performance}

From the hypothesis test, it shows that emotional quotient has a significant positive effect on employee performance, meaning that the better the emotional quotient of employees, it will improve employee performance in the company. Thus, if the higher the motivation of employees, it will make employees increase organizational commitment in the company. Meanwhile, if employee empathy is improved, it will improve the quality of employees at work. If the higher the social skills that employees have in completing work, it will be able to increase their sense of independence and quantity in working. If the employee's self-awareness is increased, it will increase the effectiveness of employees at work. This supports research conducted by Setyaningrum (2016) which states that emotional quotient influences employee performance.

\section{Effect of Intrinsic Motivation on Employee Performance}

From the hypothesis test, intrinsic motivation has a significant positive effect on employee performance, meaning that the better the intrinsic motivation of employees, the better the performance of employees in the company. Thus, if employee performance is improved, organizational commitment in the company will increase. Meanwhile, if the employee's sense of responsibility is increased, the quality of employees will increase in his work. If the company increases the development of its employees, the independence of employees at work will increase within the company. If the positive attitude of employees is enhanced at work, it will increase the effectiveness of work within the company. This supports research conducted by Taufik (2016) which states that intrinsic motivation influences employee performance.

\section{Conclusion}

Islamic leadership has a significant positive effect on intrinsic motivation, meaning that the better the Islamic leadership is implemented in the company, the better the intrinsic motivation of HR within the company. Emotional quotient has a significant positive effect on intrinsic motivation, meaning that the higher the emotional quotient in employees, the higher the intrinsic motivation felt by employees. Islamic leadership has a significant positive effect on employee performance, meaning that the better the Islamic leadership is applied in the company, the better the performance of employees in the company. Emotional quotient has a significant positive effect on employee performance, meaning that the better the emotional quotient of employees, it will improve employee performance in the company. Intrinsic motivation has a significant positive effect on employee performance, meaning that the better the intrinsic motivation of employees, the better the performance of employees in the company.

\subsection{Managerial Implication}

In terms of emotional quotient, the company should be able to encourage employees to further increase self-awareness within the company such as doing work without having to be ordered first. Also, the company should be able to encourage social skills while working to improve the work of employees in the company such as teaching public speaking or effective communication with others.

\subsection{Limitation}

This research has several limitations that require improvement and development in subsequent studies. The variables used in this study are only limited to 3 research variables. Also, the subjects used in the study were limited to personnel, staff, and nurses at Sultan Agung Islamic Hospital, Semarang, Indonesia.

\subsection{Future Research Agenda}

From the limitations of this study, further research should to add other variables besides those used in this study. The period and object of this research are expected to be expanded so that it can produce better results. 


\section{References}

Amaliya, V. (2016). Retrieved from https://vamalliya.blogspot.co.id/2016/10/kepem leaders.html

Boyatzis, R. E., \& Ron, S. (2001). Unleashing the Power of Self Directed learning, Case Western Reserve university. USA: Cleveland, Ohio.

Dewi, P. (2014). Relationship between Emotional Quotient and Learning Motivation with Learning Independence of Class V Students of Public Schools in Middle Klaten District, Academic Year 2013/2014. Yogyakarta: ePrints @ UNY.

Ghozali, I. (2014). Application of Multivariate Analysis with SPSS Program (3rd. ed.). Semarang, Diponegoro University Publishing.

Goelman, D. (2000). Emotional Quotient (Why EI is More Important than IQ). Gramedia Pustaka Utama.

Good. \& Brophy. (1990). Retrieved from http://www.definisi-pengertian.com/2016/01/pengertian-motivasiintrinsik-ekstrinsik.html

Harahap, S. (2016). The Effect of Islamic Leadership and Work Motivation on Employee Performance at PT> Bank Syariah Mandiri, Tbk, Sukaramai Sub-Branch Office Medan. Human Falah, 3(2).

Juliana \& Rozali. (2019). Effect of Emotional Quotient on Learning Motivation in Adolescents. Journal of Psychology.

Khasnah, U., \& H, L. B. (2016). The Effect of Leadership, Work Discipline, and Communication on Employee Motivation (Study of Employees at the Production Department of PT. New March Semarang). Journal of Management, 2(2).

Maulana, F. H. (2015). Influence of Intrinsic Motivation, Extrinsic Motivation and Organizational Commitment on Employee Performance at Bank BTN Malang Branch Office. Jurnal Administrasi Bisnis(JAB), 22(1).

Muizu. ( 2014 ). Effect of Leadership on Employee Performance. Pekbis Jurnal, 1-13.

Nasution, F. A. (2009). Influence of Emotional Intelligence and Self-Confidence on the Level of Accounting Understanding of UMSU Students. Jurnal Riset Akuntansi dan Bisnis, 9(2).

Sandi, S. A. (2014). The Effect of Leadership Style on Employee Motivation at Pt. Fitra Wika Pekanbaru. Skripsi thesis, Universitas Islam Negeri Sultan Syarif Kasim Riau.

Setyaningrum. (2016). The Influence of Emotional Quotient on Performance (Study of Employees of PT. Jasa Raharja, East Java Branch). East Java.

Sugiyono. (2007). Statistics for Research. Bandung: CV. Alfabeta.

Sugiyono. (2010). Educational Research Methods Quantitative, Qualitative, and R\&D Approaches. Bandung : Alfabeta.

Sugiyono. (2012). Qualitative and Quantitative Research Methods and R\&B. Bandung: Alfabeta.

Taufiq, A. (2016). The Effect of Intrinsic Motivation on Employee Performance with Job Satisfaction and Work Discipline as Mediation Variables at the Central Statistics Agency in Magelang Regency. Jurnal Bisnis Teori dan Implementasi, 7(2).

Tjahjono, H. K. (2003). The Motivation To Work (Herzberg). Jurnal Utilitas Manajemen dan Bsinis, 11(1), 55-64.

Wajdi, W. D. (2012). The Effect of Islamic Leadership, Motivation and Job Satisfaction on Employee Performance with Length of Work As a Moderating Variable. Jurnal Ekonomi Manajemen Sumber Daya, $13(2)$.

Winardi. (1996). Organizational Behaviour. Bandung: Tarsito.

Yusuf, M. (2014). Quantitative, Qualitative and Combined Research Methodologies. Jakarta: Prenadamedia Group.

\section{Copyrights}

Copyright for this article is retained by the author(s), with first publication rights granted to the journal.

This is an open-access article distributed under the terms and conditions of the Creative Commons Attribution license (http://creativecommons.org/licenses/by/4.0/). 